\title{
The Effects of International Trade on Income Convergence of the European Union Member States
}

\author{
Article history: \\ Received: 5 September 2015 \\ Sent for revision: 6 April 2016 \\ Received in revised form: 25 June 2016 \\ Accepted: 26 June 2016 \\ Available online: 11 July 2016
}

\begin{abstract}
The income convergence is a subject of debate among economists since the formulation of the Robert Solow's neoclassical growth model. The income convergence is a situation when income of poorer countries is approaching the income level of richer countries, due to more pronounced economic growth rates of poorer countries in a certain period of time. Faster growth of poorer countries is a consequence of diminishing returns on capital, which is a basic assumption of the neoclassical growth model. The subject of this paper is the effect of international trade on income convergence of the European Union member states. Regression analysis is used in this paper to test the research hypothesis: higher volume of bilateral trade causes income convergence. The results tell us in favour of the proposed hypothesis - higher volume of bilateral trade leads to income convergence.
\end{abstract}

Keywords: international trade, income convergence, neoclassical growth theory, factor-price-equalization theory, European Union

\section{Uticaj međunarodne trgovine na konvergenciju dohotka zemalja članica Evropske unije}

Apstrakt: Konvergencija dohotka je predmet rasprave među ekonomistima još od formulisanja neoklasičnog modela rasta Robert Solow-a. Konvergencija dohotka predstavlja situaciju kada se dohotak siromašnijih zemalja približava nivou dohotka bogatijih zemalja, zbog izraženije stope privrednog rasta siromašnijih zemalja u određenom vremenskom periodu. Brži rast siromašnijih zemalja posedica je opadajućih prinosa na kapital, što i predstavlja osnovnu

\footnotetext{
${ }^{1}$ University of Kragujevac, Faculty of Hotel Management and Tourism in Vrnjačka Banja, sonja.milutinovic@kg.ac.rs
} 
Milutinović S.: The Effects of International Trade on Income Convergence of the...

pretpostavku neoklasičnog modela rasta. Predmet istraživanja ovog rada je uticaj obima međunarodne trgovine na konvergenciju dohotka zemalja članica Evropske unije. U radu je korišćena regresiona analiza kako bi se testirala istraživačka hipoteza: veći obim bilateralne trgovine dovodi do konvergencije dohotka. Dobijeni rezultati nam govore u prilog postavljene hipoteze, to jest da veći obim bilateralne trgovine dovodi do konvergencije dohotka.

Ključne reči: međunarodna trgovina, konvergencija dohotka, neoklasična teorija rasta, teorija izjednačavanja cena faktora, Evropska unija.

\section{Introduction}

The convergence phenomenon is a subject of debate since the formulation of the Robert Solow's neoclassical growth model. Convergence occurs in a situation when poorer countries have faster growth than rich ones, whereas their income approaches (converges) the income of richer countries. The main cause of income convergence lies in diminishing returns of production factors, especially capital. In contrast to these traditional growth theories, recent theories do not predict the existence of convergence, nor diminishing returns.

The same case is when it comes to convergence and the effects of economic integration. On the one hand, are theorists who argue that poorer countries and those that joined the union most recently, have faster growth than the richer countries of the union. A large number of authors claim that there are certain benefits of integration: poorer countries can easily adopt technology of rich countries; mutual trade increases factor prices for "new arrival" countries, which will result in an increase of income; workers are likely to be reoriented from low-productive agricultural activities to highly-productive manufacturing jobs and services. Slaughter (1997) criticized these arguments and argued that: richer countries of the union have extensive experience in developing leading technologies, poorer countries tend to adopt labour-intensive rather than capital-intensive technology and that there is growing, not diminishing returns. Taking this into account, Slaughter (1997) argued that, in case of economic integrations, poorer countries do not have faster growth in relation to richer ones, and therefore there is income divergence rather than income convergence.

The subject of this paper is the effect of international trade on income convergence. This problem was a subject of debate in both theoretical and empirical research of many theorists (Sachs \& Warner (1995), Ben-David (1996), Ben-David and Loewy (1997), Slaughter $(1997,1998)$, Ben-David \& Kimhi (2000), Choi (2009)), whose opinions are divided on whether increased volume of international trade has positive effect on convergence or not. The 
Milutinović S.: The Effects of International Trade on Income Convergence of the...

motive for this research is in intention to contribute, at least to some extent, to the resolution of this problem.

The aim of this paper is to analyse the effect of international trade on income convergence in the European Union. For the purpose of analysis, bilateral trade of the observed countries was used.

In accordance with a defined aim and object of the research, the following statistical hypotheses will be tested in the paper: greater volume of bilateral trade leads to income convergence.

The paper is structured as follows. The second part gives an overview of the relevant literature, initially on the neoclassical growth theory, in which convergence hypothesis was first mentioned. The effect that international trade has on income convergence is presented in the third part of the paper. The fourth part deals with research methodology and data. Results and discussion are presented in the fifth section. The sixth part concludes the paper.

\section{Literature review}

Over the past sixty years the question of convergence attracted the attention of a large number of economists. This question was the focus of both theoretical and empirical research in macroeconomics, international economy and economy of development. Convergence among countries is one of the most important discoveries in the Robert Solow's neoclassical growth model from 1956 (Stanišić, 2012; Yilmaz \& Akinci, 2012).

In macroeconomics, convergence is the process of catching-up between countries of different levels of economic development (Cvetanović and Novaković, 2013). More specifically, convergence is a process when income level in less developed countries is approaching the income level of developed countries, because less developed countries have more pronounced rate of economic growth in a certain period of time.

The basic assumption of the Solow's neoclassical growth model, and the reason why the convergence occurs, is the law of diminishing returns on capital. In fact, every country in the long run, has its steady state and when it is reached, GDP per capita can grow only under the influence of technological progress. The country has a higher growth rate when is further below from its steady state. As the country approaches its steady state, GDP per capita growth rate is declining, due to diminishing returns on capital. Given that developed countries are well endowed with capital, diminishing returns are first to occur among them and thus lower GDP per capita growth rate. Capital thus moves to less developed countries, which are poorly endowed with 
Milutinović S.: The Effects of International Trade on Income Convergence of the...

capital and where the return on investment is greater and therefore faster GDP per capita growth rate. In this way, the income convergence occurs.

Neoclassical convergence model was later examined and rejected by the recent growth theory, that belongs to a group of endogenous growth theories. The biggest difference between neoclassical and new growth theories is the fact that the second one does not foresee diminishing returns, which is the most important argument of neoclassical growth theory on convergence (Vojinović, Acharya \& Prochniak, 2009). All endogenous models imply constant, or increasing returns on capital, which ultimately means rejection of the convergence hypothesis.

When it comes to the types of convergence, two concepts can be found in literature: $\beta$-convergence, which can be absolute and relative, and $\sigma$ convergence. Absolute $\beta$-convergence implies that all countries have the same steady state and differ only by initial level of income. Thus, the absolute $\beta$-convergence implies that poorer countries grow faster, to the same steady state, then the richer. Unlike the concept of absolute $\beta$-convergence, relative $\beta$-convergence implies that countries have different steady state levels, under the influence of different levels of technology, savings rates and population growth rates. Therefore, countries converge to their own, different steady states. Thus, relative $\beta$-convergence is a situation when poor countries have faster growth than rich countries, to their different steady states. The concept of $\sigma$-convergence implies the existence of convergence if the income gap between the two countries is decreasing over time. This concept became popular in the 1990s with the work of Daniel Quah. Quah (1993) claimed that $\sigma$-convergence is better than $\beta$-convergence, because it shows whether the distribution of income among countries has become more or less equal. Finally, it is important to note that $\beta$-convergence is necessary, but not sufficient condition for $\sigma$-convergence (Young, Higgins \& Levy, 2008).

Empirical research on income convergence appeared in the eighties and since then, until today, the results have been various. Baumol (1986) conducted one of the earliest research and came to the conclusion that homogeneous groups of countries are converging to a certain growth rate, while a heterogeneous group of countries shows divergence. Many studies about income convergence showed the existence of convergence at the rate of about 2\% per year worldwide (Barro \& Sala-i-Martin, 1990; Barro \& Sala-iMartin, 1991). In their study, Barro \& Sala-i-Martin (1990) confirmed the existence of income convergence in the amount of $2-2.5 \%$ per year on the example of the United States in the period from 1840 to 1988. The same study was conducted in 1991 on a sample of 73 regions in seven Western European countries starting from 1950. The convergence process was very similar to the one in the United States and was about 2\% per year. 
Milutinović S.: The Effects of International Trade on Income Convergence of the...

There are also a number of empirical studies about income convergence within the European Union (EU). The results of these studies confirm the existence of income convergence between "new" and "old" EU member states. For example, Matkowski \& Próchniak (2007) examined the existence of convergence among the countries of Central and Eastern Europe (CEE-8, countries that have, at that moment, last joined the European Union) and the EU-12 or EU-15. All CEE-8 countries have shown a tendency to grow faster than the "old" EU member states, which resulted in narrowing the income gap between the CEE-8 and the "old" EU member states (the existence of income convergence). Vojinović, Acharya \& Próchniak (2009) conducted a study on the same sample of countries, from 1992 to 2006, and came to the following conclusions: in the observed period convergence existed at the rate of $4.2 \%$ per year, while in the first half of the 1990s it failed to materialize.

Another study Vojinović, Oplotnik \& Próchniak (2010) conducted on a sample of countries that joined the EU in 2004, for the period 1992-2006, and confirmed the existence and $\beta$ and $\sigma$-convergence. In the observed period, convergence existed at the rate of $4.2 \%$ per year. The existence of convergence between "new" and "old" EU member states was proven by Varblane \& Vahter (2005) for the period from 1993 to 2004. The results have shown the existence of $\beta$-convergence, but not the $\sigma$-convergence. For the period from 2001 to 2004 the speed of convergence was 2.2\% per year.

Stanišić (2012) tested the hypothesis of convergence among the 25 countries of the EU in the period 1993-2010. The results showed the existence of $\sigma$ and $\beta$-convergence (absolute and relative). Turning the last few years into observation showed the impact of the economic crisis on income convergence. In fact, under the influence of the crisis, there were inverse results when it comes to convergence among the countries of the CEE-8 and the EU15 group. Since 2007, the first group of countries experienced divergence, while the second group of countries experienced convergence.

Rapacki \& Próchniak (2009) also tested the convergence hypothesis among the 27 former socialist countries in the period from 1990 to 2005 . The results have shown the existence of $\beta$-convergence, but not the $\sigma$-convergence. Dividing the group of 27 countries into subgroups and testing income convergence within those subgroups, they came to the conclusion that the most pronounced income convergence was within CEE-8.

\section{The effect of international trade on income convergence}

So far mentioned Solow's neoclassical growth theory applies only to a closed economy and thus ignores the effect of international trade on economic growth. Therefore, it is useless in determining convergence in the case of 
Milutinović S.: The Effects of International Trade on Income Convergence of the...

open economies. Inclusion of free trade and capital mobility between countries led to a development of neoclassical model of open economy, as a continuation of Solow's, which provides higher rates of convergence (Stanišić, 2012).

There are the following ways in which international trade can affect the convergence:

1. Knowledge transfer. Trading goods between two countries contain certain knowledge that, with trade, spills over to other countries, allowing the countries that are lagging behind to catch up with more advanced countries.

2. Increased competition. International trade can increase the pressure of increasing competition, which will force domestic firms to increase productivity, which will eventually result in higher income.

The Heckscher-Ohlin factor-price-equalization theory (FPE theory) can be a useful mean to explain the convergence among countries that trade with each other. The basic idea of this theory is that countries export goods in whose production are intensively used factors in which the country is well endowed and import goods that use intensively factors in which they are poorly endowed (Williamson, 1996). In this way, each country will specialize in the production of those goods where it has comparative advantages, which will result in the equalization of products prices. This equalization of product prices will ultimately lead to equalization of factor prices. For example, the wages should rise in poor countries relative to rich.

In his work, Slaughter $(1997,1998)$ criticized this theory and the effect that trade has on income convergence. He argues that the conclusions of FPE theory have more disadvantages:

1. FPE theory describes only the outcomes in steady state with free trade, and says nothing about the process of trade liberalization;

2. FPE theory applies only under very strict assumptions. For example, Paul Samuelson's early evidence of this theory demanded the eight strict assumptions that included, among other things: the absence of trade barriers, identical linear homogeneous technology and preferences of the region, and that all regions produce all goods;

3. FPE theory takes into account only the factor prices, but it is wellknown that apart from the price factor, the amount of these factors also affects income.

Slaughter (1998) argued that free trade leads to a divergence rather than convergence, which he proved by using the "difference-in-difference" approach. He analysed the movement of convergence between countries before and after liberalization, comparing them with the movements of convergence among randomly selected countries before and after 
Milutinović S.: The Effects of International Trade on Income Convergence of the...

liberalization. In three of the four observed groups of countries, liberalization has led to divergence rather than convergence, which only confirmed his assumption that free trade does not lead to convergence.

On the other hand, numerous studies have proven the existence of positive effect of international trade on convergence. In his study, Ben-David (1996) analysed the existence of convergence between the groups of countries that are major trading partners. He then compared results of such groups with a randomly formed groups of countries and came to the conclusion that convergence is present in the first group of countries. Ben-David \& Kimhi (2000) conducted a similar study, and came up with similar results, forming 127 pairs of countries based on export data, and 134 pairs of countries based on import data. Such formed pairs of countries showed increased speed of convergence caused by the increased volume of trade, whether they were based on export or import data.

The effect of bilateral trade on income convergence was also examined by Choi (2009). In his research he came to the conclusion that income levels in two countries converge when the bilateral trade is higher. When two countries are geographically closer and speak the same language, this convergence is more pronounced. On the assumptions of the endogenous growth model of Lucas and Romer, Ben-David and Loewy (1997) explained that the steady state growth rate depend on the rate of knowledge accumulation and that trade flows between countries facilitate the dissemination of knowledge and encourage the growth process. Thus, they argued that knowledge spillovers, which arises from increased international trade, in the long term lead to the same steady state and a similar GDP per capita. In another influential study on convergence, Sachs \& Warner (1995) classified each country on the basis of numerous criteria, as open or closed, and concluded that open countries show a strong tendency towards convergence.

\section{Research methodology and data}

As it is shown in the previous part, a number of authors investigated the relationship between income convergence and international trade, so more potential models are available for analysis in this paper. Some of them are listed below:

1. Trying to demonstrate the effect of international trade on income convergence, Ben-David (1996) first formed groups of countries which included the major trading partners. Thus formed groups he compared with randomly chosen groups of countries. If convergence was present in the first group of countries, more than in second, then it is evident that international trade have positive effect on income convergence. He 
Milutinović S.: The Effects of International Trade on Income Convergence of the...

came to the conclusion that there is a significant convergence in the group formed with countries that are major trading partners. In the contrast, in randomly chosen group, convergence hasn't been so often the case.

2. To investigate the effect of international trade on convergence, Slaughter (1998) analysed the episodes of trade liberalization. The basic idea was that if trade leads to convergence, its liberalization would accelerate convergence. To test this idea, he used the "difference-in-difference" approach. This approach compares the movement of convergence among liberalized countries before and after liberalization with the movement of convergence among the randomly selected countries before and after liberalization. The results were in contrary to the initial idea. In all four observed cases liberalization has not led to the acceleration of convergence. On the contrary, in three of four cases, after liberalization, there was a slowdown of convergence. His final conclusion was that liberalization does not in any way lead to the acceleration of convergence, but as it seemed, leads to divergence.

3. Stroomer \& Giles (2003) examined the relationship between the degree of countries' trade openness and income convergence. Observed countries were classified into smaller groups (clusters) based on the degree of openness to international trade, after which they measure the degree of convergence among countries within a single cluster using different techniques.

4. Choi (2009) had slightly more direct approach from above mentioned authors. He examined the effect of bilateral trade on income convergence. He came to the conclusion that the more two countries trade with each other, the smaller income gap between these countries will be (a larger volume of bilateral trade stimulates convergence).

Taking into consideration all the above models for purposes of analysing the effect of international trade on income convergence in this paper, the most suitable model will be a model that is used by Choi (2009). Adjusted model has the following form:

$$
\begin{aligned}
& \log (\text { PGDPijt })=\beta 0+\beta 1 * \log (\text { RATIOijt })+\beta 2 * \log (\text { DISTANCEij })+ \\
& \beta 3 * \text { Languageij }+ \text { uijt } \\
& \text { PGDP }_{\mathrm{ijt}}=\left|\mathrm{PGDP}_{\mathrm{it}}-\mathrm{PGDP}_{\mathrm{jt}}\right| /\left(\mathrm{PGDP}_{\mathrm{it}}+\mathrm{PGDP}_{\mathrm{jt}}\right) \\
& \text { RATIOijt }=\text { EXPijt } /(\text { GDPit }+ \text { GDPjt })
\end{aligned}
$$

Here subscript $i$ represents exporting country and subscript $j$ importing country. Therefore, EXP $\mathrm{P}_{i j t}$ means an export volume from country $i$ to $j$ in year $t$. The GDP $_{k t}$ stands for country k's GDP in current prices at year $t$ and PGDP $_{k t}$ stands for country $k$ 's GDP per capita in current prices at year $t$, where $t=$ 
Milutinović S.: The Effects of International Trade on Income Convergence of the...

2001, 2005, 2009, 2013. The variable DISTANCE $i j$ stands for the distance between country $i$ and country $j$. The variable Language $i j$ refers to the language spoken by the two countries whose bilateral trade is observed. If two countries speak the same language, the variable takes the value 1 , and 0 otherwise. $u_{i j t}$ is the standard error.

This regression model will be used to test the following statistical hypotheses:

$H_{0}: \beta_{1}<0$, the greater volume of bilateral trade leads to income convergence;

$\mathrm{H}_{1}: \beta_{1}>0$, the greater volume of bilateral trade does not lead to income convergence.

Absolute difference between GDP per capita in current prices is used in the analysis because technology spillovers are possible even if the goods are exported from poor country to rich country (Choi, 2009). This is because poor countries can increase the competitiveness of exports in order to compete with the goods in rich countries. For this reason, the absolute difference will be narrowed.

The analysis included two more variables: the distance between countries and the official language spoken in the country. It is assumed that, as two countries are closer to each other and speak the same language, the income gap between countries will be narrowed (Choi, 2009). Thus, it is expected that $\beta_{2}$ is positive, and $\beta_{3}$ negative.

The data for this paper are obtained from the Eurostat database (http://ec.europa.eu/eurostat). Romania, Bulgaria and Croatia are excluded from analysis because those are the countries that most recently joined the European Union. The reason for exclusion of these countries is that membership in the European Union, due to the removal of trade barriers have a major impact on the trade volume between countries. Data for the country's official language are taken from the Transition Report (EBRD, 2004). Data for the distance between two countries are taken from the web-site www.timeanddate.com

(http://www.timeanddate.com/worldclock/distance.html).

\section{Results and discussion}

The results of the regression analysis are presented in Table 1. All the resulting coefficients are negative, with statistical significance at $5 \%$. As the value of the coefficient $\beta_{1}<0$, the null hypothesis is accepted, which means that a larger volume of bilateral trade leads to income convergence. The value of the coefficient $\beta_{1}=-0.208$ means that if the intensity of trade between two countries is increased by $1 \%$, the income gap will be reduced by $0.208 \%$. 
Milutinović S.: The Effects of International Trade on Income Convergence of the...

Coefficient $\beta_{2}$ is negative, which means that the proximity of the two countries does not have a positive effect on income convergence. The negative coefficient $\beta_{3}$ confirms assumption that if two countries speak the same language, the income gap between them will decrease.

Table 1. International trade and income convergence

\begin{tabular}{|l|c|c|c|c|c|}
\hline \multirow{2}{*}{ Model } & \multicolumn{2}{|c|}{$\begin{array}{c}\text { Unstandardized } \\
\text { Coefficients }\end{array}$} & $\begin{array}{c}\text { Standardized } \\
\text { Coefficients }\end{array}$ & & \\
\cline { 2 - 3 } & $\mathrm{B}$ & Std. Error & Beta & $\mathrm{t}$ & Sig. \\
\hline (Constant) & $-1,501$ &, 230 & & $-6,539$ &, 000 \\
\hline log_ratio &,- 208 &, 014 &,- 372 & $-15,037$ &, 000 \\
\hline log_distance &,- 207 &, 039 &,- 133 & $-5,345$ &, 000 \\
\hline language &,- 740 &, 179 &,- 082 & $-4,124$ &, 000 \\
\hline
\end{tabular}

Source: Authors' calculations

In other words, the more two countries trade, the smaller the per capita income gap become. This result applies whether gaps are positive or negative (which is why absolute difference between GDP per capita in current prices was used in the analysis). This implies that a relatively poor and slow-growing exporting country can catch up with the rich and fast growing country by increasing its exports. A rich and fast-growing exporting country can also stimulate the importing country's economy by increasing its export.

Taking a closer look at the regression for individual countries, it can be seen that the statistical significance of coefficient $\beta_{1}$ is at the level higher than $5 \%$ for the following countries: Cyprus, Czech Republic, Lithuania, Malta, Poland (the results are given in Tables 2 to 6 ).

Table 2. International trade and income convergence for Cyprus

\begin{tabular}{|l|c|c|c|c|c|}
\hline \multirow{2}{*}{ Model } & \multicolumn{2}{|c|}{$\begin{array}{c}\text { Unstandardized } \\
\text { Coefficients }\end{array}$} & $\begin{array}{c}\text { Standardized } \\
\text { Coefficients }\end{array}$ & & \\
\cline { 2 - 3 } & $\mathrm{B}$ & Std. Error & Beta & t & Sig. \\
\hline (Constant) & 1,530 & 2,692 & &, 568 &, 571 \\
\hline log_ratio &,- 034 &, 052 &,- 074 &,- 654 &, 515 \\
\hline log_distance &,- 431 &, 347 &,- 172 & $-1,242$ &, 217 \\
\hline language & $-1,529$ &, 521 &,- 416 & $-2,938$ &, 004 \\
\hline
\end{tabular}

Source: Authors' calculations

This means that, in the case of these countries, the greater volume of bilateral trade does not lead to income convergence. Given that all of these countries have joined the EU in 2004 concludes that obtained results are under the influence of their recent accession to the EU and taken period of observation. This supports the decision not to include Romania, Bulgaria and Croatia in the 
Milutinović S.: The Effects of International Trade on Income Convergence of the...

analysis due to their recent accession to the $\mathrm{EU}$, as well as that membership in the EU has a great influence on the trade volume between countries. This also indicates the need to take a larger number of years into consideration in order to obtain accurate results in future analyses of the effect of international trade on income convergence.

Table 3. International trade and income convergence for Czech Republic

\begin{tabular}{|l|c|c|c|c|c|}
\hline \multirow{2}{*}{ Model } & \multicolumn{2}{|c|}{$\begin{array}{c}\text { Unstandardized } \\
\text { Coefficients }\end{array}$} & $\begin{array}{c}\text { Standardized } \\
\text { Coefficients }\end{array}$ & & \\
\cline { 2 - 3 } & $\mathrm{B}$ & Std. Error & Beta & $\mathrm{t}$ & Sig. \\
\hline (Constant) &,- 153 &, 938 & &,- 163 &, 871 \\
\hline log_ratio &,- 040 &, 089 &,- 073 &,- 447 &, 656 \\
\hline log_distance &,- 211 &, 193 &,- 179 & $-1,094$ &, 277 \\
\hline
\end{tabular}

Source: Authors' calculations

Table 4. International trade and income convergence for Lithuania

\begin{tabular}{|l|r|r|r|r|c|}
\hline \multirow{2}{*}{ Model } & \multicolumn{2}{|c|}{$\begin{array}{c}\text { Unstandardized } \\
\text { Coefficients }\end{array}$} & $\begin{array}{c}\text { Standardized } \\
\text { Coefficients }\end{array}$ & \multirow{2}{*}{ t } & Sig. \\
\cline { 2 - 3 } & \multicolumn{1}{|c|}{$\mathrm{B}$} & Std. Error & Beta & \multicolumn{1}{|c|}{$\mathrm{t}$} &, 000 \\
\hline (Constant) & $-7,540$ & 1,434 & & $-5,257$ &, 106 \\
\hline log_ratio &,- 167 &, 102 &,- 249 & $-1,638$ &, 012 \\
\hline log_distance &, 712 &, 277 &, 392 & 2,574 &, 012 \\
\hline
\end{tabular}

Source: Authors' calculations

Table 5. International trade and income convergence for Malta

\begin{tabular}{|l|c|c|c|c|c|}
\hline \multirow{2}{*}{ Model } & \multicolumn{2}{|c|}{$\begin{array}{c}\text { Unstandardized } \\
\text { Coefficients }\end{array}$} & $\begin{array}{c}\text { Standardized } \\
\text { Coefficients }\end{array}$ & & \\
\cline { 2 - 3 } & $\mathrm{B}$ & Std. Error & Beta & $\mathrm{t}$ & Sig. \\
\hline (Constant) & $-7,888$ & 1,898 & & $-4,155$ &, 000 \\
\hline log_ratio &,- 030 &, 065 &,- 046 &,- 464 &, 644 \\
\hline log_distance &, 823 &, 248 &, 330 & 3,321 &, 001 \\
\hline
\end{tabular}

Source: Authors' calculations

Table 6. International trade and income convergence for Poland

\begin{tabular}{|l|c|c|c|c|c|}
\hline \multirow{2}{*}{ Model } & \multicolumn{2}{|c|}{$\begin{array}{c}\text { Unstandardized } \\
\text { Coefficients }\end{array}$} & $\begin{array}{c}\text { Standardized } \\
\text { Coefficients }\end{array}$ & & \\
\cline { 2 - 3 } & $\mathrm{B}$ & Std. Error & Beta & $\mathrm{t}$ & Sig. \\
\hline (Constant) & $-7,609$ & 1,278 & & $-5,954$ &, 000 \\
\hline log_ratio &, 133 &, 100 &, 158 & 1,341 &, 183 \\
\hline log_distance & 1,062 &, 227 &, 552 & 4,673 &, 000 \\
\hline
\end{tabular}

Source: Authors' calculations 
Milutinović S.: The Effects of International Trade on Income Convergence of the...

The maximum value of the coefficient $\beta_{1}$ is in the case of Austria (the results are shown in Table 7 ). Its value of $-0,708$ means that if the intensity of trade between Austria and its trading partners is increased by $1 \%$, the income gap between them will be reduced by $0.708 \%$.

Table 7. International trade and income convergence for Austria

\begin{tabular}{|l|c|c|c|c|c|}
\hline \multirow{2}{*}{ Model } & \multicolumn{2}{|c|}{$\begin{array}{c}\text { Unstandardized } \\
\text { Coefficients }\end{array}$} & $\begin{array}{c}\text { Standardized } \\
\text { Coefficients }\end{array}$ & & \\
\cline { 2 - 4 } & $\mathrm{B}$ & Std. Error & Beta & $\mathrm{t}$ & Sig. \\
\hline (Constant) & 1,888 &, 983 & & 1,921 &, 058 \\
\hline log_ratio &,- 708 &, 143 &,- 621 & $-4,945$ &, 000 \\
\hline log_distance & $-1,241$ &, 199 &,- 740 & $-6,242$ &, 000 \\
\hline language &,- 428 &, 647 &,- 062 &,- 663 &, 509 \\
\hline
\end{tabular}

Source: Authors' calculations

Luxembourg has the lowest value of the coefficient $\beta_{1}$ at the level of $-0,108$ (the results are shown in Table 8). This means that the income gap between Luxembourg and its trading partners will be reduced by $0.108 \%$ if the intensity of trade between them is increased by $1 \%$.

Table 8. International trade and income convergence for Luxembourg

\begin{tabular}{|l|c|c|c|c|c|}
\hline \multirow{2}{*}{ Model } & \multicolumn{2}{|c|}{$\begin{array}{c}\text { Unstandardized } \\
\text { Coefficients }\end{array}$} & $\begin{array}{c}\text { Standardized } \\
\text { Coefficients }\end{array}$ & \multirow{2}{*}{ Sig. } \\
\cline { 2 - 4 } & $\mathrm{B}$ & Std. Error & Beta & $\mathrm{t}$ & Sinn \\
\hline (Constant) & $-2,201$ &, 416 & & $-5,289$ &, 000 \\
\hline log_ratio &,- 108 &, 046 &,- 301 & $-2,341$ &, 021 \\
\hline log_distance &, 100 &, 080 &, 171 & 1,254 &, 213 \\
\hline language &,- 008 &, 191 &,- 004 &,- 043 &, 966 \\
\hline
\end{tabular}

Source: Authors' calculations

This result can be associated with the fact that Luxembourg has the highest GDP and GDP per capita in the EU. According to the Eurostat, GDP and GDP per capita for Luxembourg for the year 2013 is $45.288,1$ million $€$ and $83.100 €$, respectively. This speaks in favour of the above mentioned assertions in the paper: "new arrival" and poorer countries of union benefit more from integration than "old" members and richer countries of union.

\section{Conclusion}

The issue of convergence has become popular among economists in the 1960s after it was first mentioned in Robert Solow's neoclassical growth 
Milutinović S.: The Effects of International Trade on Income Convergence of the...

model. From that time until the present day, there is no agreement among economists about whether convergence among countries with different level of development exists or not. As the Solow's growth model is related to the closed economies, it hadn't been able to explain the effect of international trade on income convergence. Hecksche-Ohlin factor price equalization theory can be a useful tool for explaining convergence between countries that trade with each other (and therefore are open economies).

Empirical work on the effect of international trade on income convergence occurred in the late twentieth century, in the works of Sachs \& Warner (1995), Ben-David (1996), Ben-David and Loewy (1997), Slaughter (1998). A certain number of these authors proven that there is a positive link between international trade and openness of a country, on the one hand and convergence on the other, that is that, greater international trade leads to convergence. On the other hand, Slaughter (1998) criticized the conclusions and assumptions of Hecksche-Ohlin factor price equalization theory, and in his work proved that higher volume of international trade does not lead to convergence, even in some cases causes divergence.

The research subject of this paper is the effect of international trade on income convergence in the EU member states. The question of relations between international trade and convergence in the EU is very interesting, precisely because the EU accession erases all trade barriers, which results in a greater trade volume. The motive for this research is in its intention to, at least in a small way, contribute to solving the questions whether the increased volume of international trade leads to convergence or not. The survey was conducted in the EU countries, except Bulgaria, Romania and Croatia. Regression model was used to test the relationship between bilateral trade and income convergence. Gross domestic product per capita in current prices was used as a measure of income convergence. Empirical results support the hypothesis that income level tend to converge when bilateral trade increases, in the following proportions: if the intensity of trade between two countries is increased by $1 \%$, the income gap will be narrowed by $0.208 \%$. Two more coefficients were used in analysis: distance and language, and both of them are negative and significant at $5 \%$. This means that if two countries share the same language, the effect is even greater. However, the geographical proximity does not have this effect. To conclude, integrations contribute to narrowing income gaps rather than widening them between rich and poor countries.

These results should be taken with caution, because the small number of years were taken into account $(2001,2005,2009,2013)$. Therefore, we can say that the results of this analysis are preliminary studies which aim to show the methodological aspects of the future work with a larger database. 
Milutinović S.: The Effects of International Trade on Income Convergence of the...

\section{Reference}

Akinci, M., \& Yilmaz, O. (2012). Per Capita Income Convergence among European Union Countries: Haldane: Hall Approach. Marmara Journal of European Studies, 20(2), 39-61. Retrieved from http://web.b.ebscohost.com.proxy.kobson.nb.rs 2048/ehost/detail/detail?vid=4\&sid=bf7a6e50-c168-4524-a65fcfb7350bca79\%40sessionmgr110\&hid=105\&bdata=JnNpdGU9ZWhvc3QtbGl2Z Q\%3d\%3d\#db=aph\&AN=91793431

Barro, R.J., \& Sala-i-Martin, X. (1990). Economic Growth and Convergence across United States. NBER Working paper Series, 3419, 549-580. doi:10.3386/w3419

Barro, R.J., \& Sala-i-Martin, X. (1991). Convergence across States and Regions. Brookings Papers on Economic Activity, 1, 107-182. Retrieved from https://ideas.repec.org/a/bin/bpeajo/v22y1991i1991-1p107-182.html

Baumol, W.J. (1986). Productivity Growth, Convergence, and Welfare: What the LongRun Data Show. American Economic Review, 76(5), 1072-1085. Retrieved from http://web.b.ebscohost.com.proxy.kobson.nb.rs

2048/ehost/resultsadvanced?sid=6b97cb21-2445-4929-bb9b-

$8060 \mathrm{a} 877 \mathrm{db} 6 f \% 40$ sessionmgr114\&vid=3\&hid=105\&bquery $=\mathrm{TI}+($ Productivity $+\mathrm{Gr}$ owth\%2c+Convergence $\% 2 c+A N D+$ Welfare\%3a+What+the+Long-

Run+Data+Show)\&bdata=JmRiPWFwaCZkYj1idWgmZGI9ZXJpYyZkYj1mNWg mZGI9Y21IZG0mdHIwZT0xJnNpdGU9ZWhvc3QtbGI2ZQ\%3d\%3d

Ben-David, D. (1996). Trade and Convergence among Countries. Journal of International Economics, 40, 279-298. Retrieved from http://www.tau.ac.il/ danib/trade-growth/tradconv.pdf

Ben-David, D., \& Loewly, M.B. (1997). Free Trade, Growth and Convergence. NBER Working paper Series, 6095, 143-170. doi:10.3386/w6095

Ben-David, D., \& Kimhi, A. (2000). Trade and the Rate of Income Convergence. J NBER Working Paper, 7642, 419-441. doi:10.3386/w7642

Choi, C. (2009). Does Bilateral Trade Lead to Income Convergence?, Panel evidence. Journal of Economic Development,34(1), 71-79. Retrieved from https://ideas.repec.org/a/jed/journl/v34y2009i1p71-79.html

Cvetanović, S., \& Novaković, I. (2013). Inovacija i razvojna konvergencija u modelu rasta Roberta Soloua. Економика,29(4), 1-9. Retrieved from http://www.ekonomika.org.rs/sr/ekonomika casopis.html

-European Bank for Reconstruction and Development. (2004). Transition report.

Matkowski, Z., \& Próchniak, M. (2007). Economic Convergence Between the CEE-8 and the European Union. Eastern European Economics, 45(1), 59-76. doi:10.2753/EEE0012-8775450103

Quah, D. (1993). Galton's Fallacy and Tests of the Convergence Hypothesis. Scandinavian Journal of Economics, 95(4), 427. doi:10.2307/3440905

Rapacki, R., \& Próchinak, M. (2009). Real Beta and Sigma Convergence in 27 Transition Countries, 1990-2005. Post-Comunist Economies, 21(3), 307-326. doi: 0.1080/14631370903090616

Sachs, J., \& Warner, A. (1995). Economic Reform and the Process of Global Integration. Brooking Papers on Economic Activity, 1, 1-118. Retrieved from 
Milutinović S.: The Effects of International Trade on Income Convergence of the...

http://econpapers.repec.org/article/binbpeajo/v 3a26 3ay 3a1995 3ai 3a19951 3ap 3a1-118.htm

Slaughter, M.J. (1997). Per Capita Oncome Convergence and the Role of International Trade. American Economic Review,194-199. NBER Working paper Series No. 5897, 549-580. doi:10.3386/w5897

Slaughter, M.J. (1998). International Trade and Per Capita Income Convergence: A Difference-in-Differences Analysis.NBER Working paper Series, 6557, 203-228. doi:10.3386/w6557

Stanišić, N. (2012). The Effects of Economic Crisis on the Income Convergence in the European Union. Acta Oeconomica,62(2), 161-182. doi:10.1556/Aoecon.62.2012.2.2

Stroomer, C., \& Giles, D.E.A. (2003). Income Convergence and Trade Openness: Fuzzy Clustering and Time Series Evidence. Econometrics Working Paper Series, University of Victoria, Retrieved from http://econpapers.repec.org/paper/vicvicewp/0304.htm

Varblane, U., \& Vahter, P. (2005). An Analysis of the Economic Convergence Process in the Transitions Countries. Tartu University Working Paper, 37. Retrieved from https://ideas.repec.org/p/mtk/febawb/37.html

Vojinović, B., Acharya, S., \& Prochniak, M. (2009). Convergence Analysis Among the Ten European Transition Economies. Hitotsubashi Journal of Economics, 50, 123-141. Retrieved from http://econpapers.repec.org/article/hithitjec/v 3a50 3ay 3a2009 3ai 3a2 3ap 3a17-35.htm

Vojinović, B., Oplotnik, Ž., \& Próchniak, M. (2010). EU Enlargement and Real Economic Convergence. Post-Comunist Economies, 22(3), 303-322. doi: $10.1080 / 14631377.2010 .498681$

Williamson, J.G. (1996). Globalization, Convergence, and History. NBER Working paper Series, 5259, 1-30. doi:10.3386/w5259

Young, A.T., Higgins, M.J., \& Levy, D. (2008). Sigma Convergence versus Beta Convergence: Evidence from U.S. County-Level Data. Journal of Money, Credit and Banking, 40(5), 1083-1093. doi:10.1111/j.1538-4616.2008.00148.x

Retrieved from http://www.timeanddate.com/worldclock/distance.html 